\title{
Protective roles of adiponectin in obesity- related fatty liver diseases: mechanisms and therapeutic implications
}

\author{
Adiponectina e seu papel na proteção contra a doença hepática \\ gordurosa na obesidade: mecanismos e implicações terapêuticas
}

Yu Wang ${ }^{1,2}$, Mingyan Zhou ${ }^{1,2}$, Karen S. L. Lam ${ }^{2,3}$, Aimin $\mathrm{Xu}^{1,2,3}$

\begin{abstract}
Adiponectin is an insulin-sensitizing adipokine possessing multiple beneficial effects on obesity-related medical complications. This adipokine is secreted from adipocytes into the circulation as three oligomeric isoforms, including trimer, hexamer and the high molecular weight (HMW) oligomeric complex. Each oligomeric isoform of adiponectin possesses distinct biological properties and activates different signaling pathways in various target tissues. The hepato-protective activities have been demonstrated by many clinical and experimental studies. The decreased level of serum adiponectin represents an independent risk factor for nonalcoholic fatty liver disease (NAFLD) and liver dysfunctions in humans. In animals, elevation of circulating adiponectin by either pharmacological or genetic approaches leads to a significant alleviation of hepatomegaly, steatosis and necro-inflammation associated with various liver diseases. In adiponectin knockout mice, there is a pre-existing condition of hepatic steatosis and mitochondria dysfunction, which might contribute to the increased vulnerabilities of these mice to the secondary liver injuries induced by obesity and other conditions. This review aims to summarize recent advances on delination of the structural, molecular and cellular mechanisms underlying the hepato-protective properties of adiponectin. Arq Bras Endocrinol Metab. 2009;53(2):201-212.
\end{abstract}

Keywords

Adiponectin; NASH; hepatic steatosis; insulin resistance

\section{RESUMO}

A adiponectina é uma adipocitocina com ação insulino-sensibilizadora com múltiplos efeitos benéficos sobre as complicações clínicas da obesidade. Essa adipocitocina é secretada pelos adipócitos na circulação sistêmica em três isoformas oligoméricas, incluindo as formas em trímeros, hexâmeros e complexas de alto peso molecular (HMW). Cada forma oligomérica da adiponectina apresenta propriedades biológicas distintas e ativam diferentes vias de sinalização celular em diversos tecidos. Suas atividades hepatoprotetoras têm sido descritas em vários estudos clínicos e experimentais. Em humanos, os níveis reduzidos da adiponectina sérica, características da obesidade, representam um fator de risco independente para a doença hepática gordurosa não-alcoólica (NAFLD), incluindo variados graus de disfunções hepáticas. Em animais, a elevação dos níveis circulantes de adiponectina, por manipulações genéticas ou farmacológicas, conduz a uma atenuação da hepatomegalia, da esteatose e da necroinflamação usualmente associadas a várias doenças hepáticas. No animal sem o gene da adiponectina (knockout), existe uma condição preexistente de esteatose e disfunção mitocondrial que contribui para a vulnerabilidade desses animais aos processos de lesões teciduais hepáticos induzidos pela obesidade e outras condições. Esta revisão sumariza os recentes avanços na compreensão e caracterização dos mecanismos celulares, moleculares e estruturais das ações hepatoprotetoras da adiponectina. Arq Bras Endocrinol Metab. 2009;53(2):201-212.

Descritores

Adiponectina; NASH; esteatose hepática; resistência à insulina
1 Department of Pharmacology ${ }^{2}$ Research Center for Heart, Brain, Hormone and Healthy Ageing ${ }^{3}$ Department of Medicine, University of Hong Kong, Hong Kong, China
Correspondence to:

Yu Wang

Department of Pharmacology,

University of Hong Kong, L2-53, 21

Sassoon Road

Hong Kong

yuwanghk@hku.hk

Received in Dec/01/2008 Accepted in Jan/10/2009 


\section{INTRODUCTION}

$\mathrm{N}$ onalcoholic fatty liver disease (NAFLD) is the most common type of chronic liver injury in many countries $(1,2)$. NAFLD includes a spectrum of syndromes ranging from simple steatosis, nonalcoholic steatohepatitis (NASH) to fibrosis, cirrhosis and hepatocellular carcinoma (3). The overall prevalence of NAFLD is $15 \%-40 \%$ in Western countries and $9 \%-40 \%$ in the Asian population (4), and has dramatically increased over the past 15 years, mainly as a consequence of its close association with two major worldwide epidemics, obesity and type 2 diabetes mellitus (T2DM) (5). Mortality in patients with NAFLD is significantly higher than that in the age and gender-matched general population (6). Disease progression to NASH and cirrhosis appears to be very slow, and only a few patients develop life-threatening advanced liver disease. In many cases of NAFLD, the risks of developing metabolic and cardiovascular morbidities are much higher than of hepatic diseases $(7,8)$. In fact, NAFLD is considered as the hepatic manifestation of the metabolic syndrome, which refers to a cluster of cardiovascular risk factors associated with insulin resistance, including central obesity, hypertension, dyslipidemia and T2DM (9). The association between NAFLD and metabolic syndrome has been established in many cross-sectional and prospective studies (8). NAFLD significantly increases the risk of diabetes and is a better predictor of the development of metabolic disorders than obesity itself (10). Recent studies have reported an association of NAFLD with multiple classical and non-classical risk factors for cardiovascular diseases (7). NAFLD predicts future cardiovascular events independently of other prognostic factors, including the component of metabolic syndrome. In summary, NAFLD is associated with a future high incidence of metabolic and cardiovascular complications and should be considered beyond a hepatic disease confined to classical boundaries. Understanding the disease and its management is a vital issue in nowadays clinical practice.

\section{PATHOGENESIS OF NAFLD}

Although the pathogenesis of NAFLD remains largely unknown, insulin resistance, oxidative stress and inflammation play important roles in the development and progression of NAFLD $(11,12)$. Fatty liver itself is a status of insulin resistance. Hepatic fat accumulation can lead to hepatic insulin resistance, which may occur before the alterations in peripheral insulin actions and may induce peripheral insulin resistance $(13,14)$. Insulin regulates the uptake, oxidation and storage of fuel within insulin-sensitive tissues including the liver, skeletal muscle and fat. Peripheral insulin resistance impairs glucose uptake from blood into skeletal muscle and adipose tissue; serum non-esterified fatty acid (NEFA) levels may also be elevated due to the failure of insulin to suppress lipolysis $(15,16)$. In the liver, insulin resistance is associated with increased cellular contents of fatty acids and their metabolites (fatty acyl-CoAs, diacylglycerides and ceramides) (17-19). Hyperinsulinemia caused by insulin resistance, in the presence of increased circulating levels of NEFA, enhances the hepatic uptake of fatty acid and promotes lipogenesis $(1,20)$. In addition, defects in mitochondrial $\beta$-oxidation, enhanced fatty acid synthesis and impaired secretion of triacylglyceride (TG)-rich very low density lipoproteins (VLDL) also contribute to hepatic steatosis (21-23). A growing body of evidence from animal models suggests a "two-hit" hypothesis responsible for the development of NAFLD (24-26). With this theory, the first hit is the occurrence of fatty liver (steatosis), followed by a second event leading to the development of NASH. The potential secondary hits include endotoxin exposure, alcohol consumption and virus infections etc., which expand hepatic lipid stores, cause hepatocellular injury, promote oxidative stress and inflammation in the liver. Lipotoxicity and the release of cytokines and other pro-inflammatory mediators play important roles during this process. Moreover, inflammation in the development of NASH can further impede insulin signaling (27). Histologically, NASH is manifested by hepatocyte nuclear ballooning, hepatocyte apoptosis, Mallory's hyaline and inflammation foci (28). NAFLD patients have a high circulating FFAs level correlating with the severity of liver disease. Overloaded FFAs may exhibit lipotoxicity by inducing the expression of proinflammatory cytokines such as tumor necrosis factor alpha $($ TNF- $\alpha)(29)$.

\section{VISCERAL OBESITY, ADIPOKINES AND NAFLD}

Obesity, especially visceral obesity, is frequently associated with NAFLD and their coexistence in the same individual increases the likelihood of having more advanced forms of liver disease $(30,31)$. NAFLD occurs in $60 \% \sim 95 \%$ of people with obesity (32). Visceral fat is 
a key mediator of NASH and is strongly associated with alanine aminotransferase (ALT) levels in the nondiabetic obese population $(31,33,34)$. The importance of visceral fat in the pathogenesis of NAFLD has also been shown in many animal models including $f a / f a$ obese rats. In these animals, surgical resection of intraabdorminal fat depots reverses hepatic insulin resistance and steatosis (35).

Recent evidence suggests that visceral adipose tissue is a metabolic and inflammatory organ that signals and modulates the action and metabolism of the brain, liver, muscle and cardiovascular system $(36,37)$. The imbalanced production of pro- and anti-inflammatory adipokines secreted from fat contributes to the pathogenesis of NAFLD (38). Modulation of endocrine/ immune/inflammatory interactions of adipose tissue may provide novel therapeutic (pharmacologic) targets for the treatment of NAFLD. For example, in patients with severe lipodystrophy, injection with leptin reverses nonalcoholic fatty liver diseases $(39,40)$. However, in cases of NAFLD associated with obesity, serum levels of leptin are increased and the liver becomes refractory to the "anti-steatotic" effects of leptin (41-43). Leptin infusion is therefore unlikely to be of therapeutic values for patients with NAFLD. Tumor necrosis factor $\alpha$ $(\mathrm{TNF} \alpha)$, a pro-inflammatory adipokine, interferes with insulin signaling and favors steatosis, and may play a casual role in the pathogenesis of NASH (38). Circulating levels of TNF $\alpha$ and hepatic expression of its type 1 receptor are increased in NASH, but could not discriminate steatohepatitis from steatosis (44-46). Neutralization of TNF $\alpha$ activity improves fatty liver disease in animals (47). Conversely, nutritional steatohepatitis can still be produced experimentally in both TNF $\alpha$ and TNF $\alpha$ type 1 receptor knockout mice, suggesting that this adipokine might not be an essential mediator of NAFLD $(48,49)$.

In contrast to leptin and TNF $\alpha$, adiponectin is more closely implicated in the pathogenesis of NAFLD/NASH. Unlike other adipokines, serum levels of adiponectin are decreased in obesity and its associated medical complications (50). A negative association between serum levels of adiponectin and liver enzyme levels has been shown in healthy subjects (51). Numerous epidemiological investigations in diverse ethnic groups have identified lower adiponectin level as an independent risk factor for non-alcoholic fatty liver diseases and liver dysfunctions (37). Compared with healthy controls, adiponectin levels are lower by more than $50 \%$ in NASH patients (52). Adiponectin expression is decreased by $20 \% \sim 40 \%$ during the development of NAFLD, from simple steatosis to NASH $(52,53)$. Moreover, NASH patients with lower levels of adiponectin show higher grades of inflammation, suggesting that adiponectin deficiency is an important risk factor for the development of fatty liver, steatohepatitis and other forms of liver injuries (52-55). In patients with T2DM, plasma adiponectin concentrations are inversely related to hepatic fat content (56). Hui and cols. have shown a direct relationship between hypoadiponectinemia and NASH independent of insulin resistance (52). Animalbased studies have demonstrated that adiponectin possesses potent protective activities against various forms of liver injuries, including those induced by carbon tetrachloride, lipopolysaccharide (LPS)/D-galactosamine, pharmacological compounds, bile duct ligations and methionine-deficient diet etc. (57-61). In animal models of both alcoholic and nonalcoholic steatohepatitis, exogenous adiponectin reduces hepatomegaly, depletes lipid accumulation, quenches hepatic inflammation and decreases hepatic expression and plasma concentrations of TNF $\alpha$ (62). Adiponectin knockout mice exhibit an enhanced pattern of hepatic fibrosis induced by carbon tetrachloride (58). The lack of adiponectin expression could accelerate hepatic tumor formation in a NASH model in mice (63). Among the known adipokines, adiponectin stands out for its insulin-sensitizing and antiinflammatory roles, and may be used as a promising drug candidate for the treatment of liver diseases.

\section{STRUCTURAL BASIS AND SIGNALING MECHANISMS UNDERLYING THE HEPATO- PROTECTIVE FUNCTIONS OF ADIPONECTIN}

Adiponectin, also termed Acrp30, AdipoQ, apMl or GBP28, was originally identified by four independent groups in both mice and humans (64-67). This adipokine has attracted much attention because of its multiple beneficial effects on a cluster of obesity-related metabolic and cardiovascular dysfunctions. Hypoadiponectinemia is a key etiologic factor contributing to almost all the major pathological conditions associated with obesity (68). The physiological functions and clinical relevance of adiponectin in obesity-related medical complications have been extensively reviewed elsewhere $(50,69-72)$. In the following sections, we will discuss recent advances on the structural regulations of adiponectin as well as the molecular evidences support- 
ing the role of adiponectin as a major protective agent against obesity-related NAFLD.

\section{Polymorphism of the multimeric structures of adiponectin}

A unique feature of adiponectin structure is its ability to assemble into several characteristic oligomeric isoforms, including trimer (low molecular weight, LMW), hexamer (middle molecular weight, MMW) and the oligomeric complexes consisting of 18 protomers or above (high molecular weight, HMW). (73). Adiponectin presents predominantly in the circulation as these three oligomeric complexes (74-79). The trimeric adiponectin is the basic building block of adiponectin. The subunits in the trimer are associated via hydrophobic interactions. The hexameric adiponectin is formed by two LMW adiponectin molecules linked by disulfide bonds. The structural properties of the HMW adiponectin remain poorly characterized due to the heterogeneous nature of this isoform. Analysis of adiponectin oligomers by non-denaturing and non-heating gel electrophoresis shows that the human HMW adiponectin composes of a mixture of 18-30 mers, or even larger molecular weight species $(73,78,80,81)$. Dynamic light scattering and transmission electron microscopy shows that the bovine HMW adiponectin forms a bouquet-like architecture resembling that of complement Clq (82). Six globular objects can be seen atop a thin stalk, which presumably correspond to the six LMW adiponectins. The stalks bunch together in a manner that is consistent with the requirement for $\mathrm{NH} 2$-terminal disulfide bonding. The side views of HMW adiponectin suggest a conical structure of the oligomer with the $\mathrm{COOH}$ terminal portion forming the base. Interestingly, these globular domains are arranged in a tight ring. This circular arrangement might enable polyvalent interactions of the globular domains with a single receptor. Recently, the HMW oligomeric structures formed by multiples of adiponectin trimers have been determined by single-particle analysis of electron micrographs (83). Pleiomorphic ensembles of collagen-like stretches of the trimers lead to a highly dynamic structure of HMW adiponectin, which could be classified into two major classes, the fan-shaped (class I) and bouquet-shaped (class II). In both of these conformations, the globular domains assume a variety of arrangements, covering an area of up to $4.9 \times 105 \AA^{2}$ and up to $320 \AA$ apart. The conformational flexibility of the HMW oligomer can allow it to access and cluster disparate target ligands or receptors, which may be necessary to activate cellular signaling leading to the remarkable functional diversity of adiponectin.

\section{The HMW adiponectin as a major bioactive form in liver}

Obese individuals have different distribution of adiponectin oligomers compared with lean control. Relatively lower content of HMW adiponectin is closely associated with obesity-related metabolic complications (81). The increases in the ratio of HMW versus total adiponectin, but not total adiponectin level per se, correlate well with improved insulin sensitivity during treatment with the insulin-sensitizing drug thiazolidinediones in both diabetic mice and patients with T2DM. On the other hand, weight reduction by either calorie restriction or gastric bypass surgery results in a selective elevation of the HMW adiponectin, but not the trimeric and hexameric complexes (84-86). In line with these data from the epidemiological studies, there is also genetic evidence supporting the role of HMW adiponectin as a major insulin-sensitizing isoform in humans. Kadowaki and colleagues have reported two rare mutations (G84R and G90S) located within the collagenous domain which are closely associated with insulin resistance and T2DM (76). Interestingly, subjects with either of these mutations have extremely low levels of HMW adiponectin. Moreover, recombinant adiponectin with either of these mutations expressed in NIH-3T3 fibroblasts failed to form HMW oligomers. An independent inverse association exists between ALT and HMW adiponectin (87). Taken together, these epidemiological and genetic data suggest that the beneficial effects of adiponectin in humans might be mediated primarily by its HMW isoform, and the deficiency of this oligomer is an important etiological factor that links obesity with its medical complications.

Evidence from both in vitro and animal-based studies also supports the role of the HMW oligomer as the major active form in mediating the multiple actions of adiponectin in the liver tissue. Recombinant adiponectin produced from mammalian cells, which can form the HMW oligomers, potently decreases hyperglycemia in diabetic mice through inhibition of hepatic glucose production (88). However, bacterially generated fulllength adiponectin, which lacks the capacity to form the HMW adiponectin, is almost inactive. Intravenous 
injection of the HMW adiponectin, but not the hexameric adiponectin, leads to a dose-dependent decrease in serum glucose levels (81). The formation of the HMW oligomers is obligatory to mediate the insulinsensitizing effects of adiponectin on suppression of hepatic gluconeogenesis in primary rat hepatocytes $(80)$. Acute injection of recombinant adiponectin enriched with the HMW oligomers results in a marked activation of AMP-activated kinase (AMPK) in the liver, while chronic infusion with this protein leads to prolonged alleviation of hyperglycemia and insulin resistance in $d b / d b$ diabetic mice (89). These animal-based evidences are consistent with the clinical observations showing that the ratio of $\mathrm{HMW} /$ total adiponectin correlates closely with hepatic insulin sensitivity (81). The role of the HMW oligomer as a predominant active form of adiponectin mediating its hepatic actions is also supported by two recent independent reports demonstrating that the insulin-sensitizing effects of the PPAR $\gamma$ agonists thiazolidinediones were diminished in $o b / o b$ obese mice with the targeted mutation of the adiponectin gene $(90,91)$. Notably, treatment with thiazolidinediones has been shown to cause a selective elevation of the HMW oligomeric adiponectin $(79,81)$. In addition to the hepatic insulin-sensitizing activity, the HMW adiponectin has also been suggested to be the most potent isoform for alleviation of fatty liver disease in high fat diet-induced obese mice (92), and inhibition of apolipoprotein B and E release from human hepatocytes (93). HMW adiponectin dose-dependently suppressed growth factor-induced hepatic stellate cell proliferation (94). Together, these data suggest that the beneficial effects of adiponectin in the hepatic tissue are mediated predominantly by its HMW form.

\section{Receptors and postreceptor signaling pathways mediating the hepato-protective functions of adiponectin}

Two adiponectin receptors (adipoRl and adipoR2) have been identified and found to be expressed in various tissues (95). AdipoRl is abundantly expressed in skeletal muscles, whereas adipoR2 is present predominantly in the liver, suggesting a role of adipoR2 in hepatic adiponectin signaling $(68,96)$. The physiological roles of adipoRl and adipoR 2 have recently been investigated by several laboratories in adipoRl/2 knockout mice. Both adipoR $I$ and adipoR 2 knockout mice exhibit mild insulin resistance (97). In adipoR $1 / R 2$ double knockout mice, the binding and actions of adiponectin are abolished, resulting in increased tissue triglyceride content, inflammation and oxidative stress (97). AdipoR2 knockout mice reported by Liu and cols. displayed reduced diet-induced insulin resistance, but promoted T2DM (98). These data support the physiological roles of adipoRl and adipoR2 as the predominant receptors for adiponectin in the regulation of glucose and lipid metabolism. Despite this information, the detailed roles and expression of adipoRs in NAFLD are not conclusive (99-102).

Adiponectin has been shown to stimulate AMPactivated protein kinase (AMPK) in almost all its major target tissues, including skeletal muscle, liver, heart, endothelium, adipocytes and brain $(75,89,103-106)$. Notably, most biological effects of adiponectin in these target tissues are abrogated by expression of a dominant negative version of AMPK, supporting its obligatory role in mediating adiponectin's multiple actions. The precise mechanisms whereby adiponectin activates AMPK through its receptors remain to be determined. APPL1, an adaptor protein containing pleckstrin homology domain, phosphotyrosine binding domain and leucine zipper motif, appears to be a key signaling molecule that couples adiponectin receptors and its downstream AMPK activation $(103,107)$. Adiponectin enhances the binding of APPLl to both adipoRl and adipoR2, and these interactions are essential for subsequent phosphorylation and activation of AMPK. Studies also indicate the important role of APPLl in the metabolic syndrome $(108,109)$. AMPK activation in turn phosphorylates acetyl Coenzyme A carboxylase (ACC) and attenuates ACC activity. Inhibition of ACC reduces lipid synthesis and enhances fatty acid oxidation by blocking the production of malonyl-CoA, an allosteric inhibitor of carnitine palmitoyl transferase 1 (CPT-1), the rate-limiting enzyme in fatty acid oxidation. In addition, activation of AMPK downregulates the expression of sterol regulatory element-binding protein lc (SREBPlc), a transcription factor that regulates cholesterol and lipid synthesis. Reduction of SREBPlc results in downregulation of genes involved in lipogenesis, including ACC, fatty acid synthase (FAS), and glycerol-3-phosphate acyltransferase (GPAT) $(104,110,111)$.

PPAR $\alpha$ is a transcription factor controlling the transcription of a panel of genes encoding fatty acid oxidation enzymes, such as FATP, acyl-CoA oxidase (ACOX) and long chain acyl-CoA synthetase (LCAS). Adiponectin stimulates PPAR $\alpha$ activity possibly through PPAP $\gamma$ 
coactivator-1 $\alpha$ (PGC-1 $\alpha)$ (112). These signaling pathways mediated by adiponectin lead to enhanced fat oxidation, reduced lipid synthesis and prevention of hepatic steatosis (Figure 1).

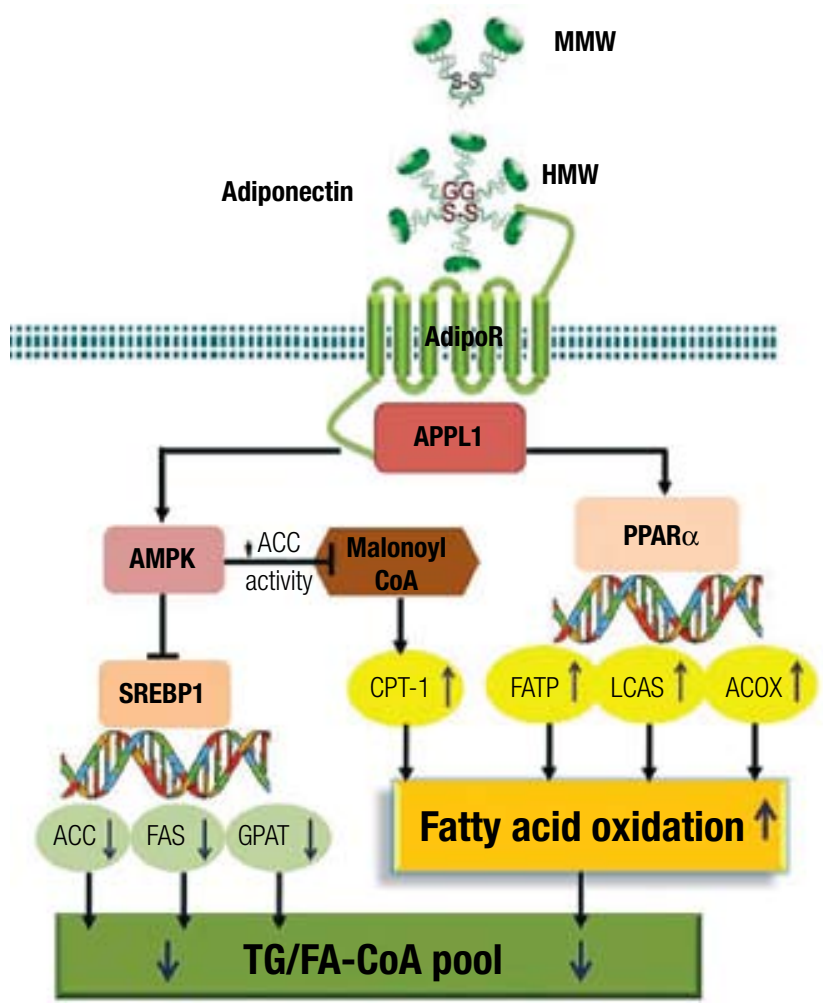

Figure 1. A summary of multiple signaling pathways that mediate the anti-steatotic effects of adiponectin.

\section{Cellular mechanisms contributing to the anti- inflammatory activities of adiponectin in NAFLD}

Inflammatory cytokines are key mediators of hepatic inflammation, cell death, fibrosis, as well as regeneration after massive or focal liver injury $(38,113)$. Adiponectin levels are negatively associated with mediators of inflammation, including IL-6 and C-reactive protein (CRP); but positively related to anti-inflammatory cytokine IL-10 $(114,115)$. It suppresses TNF- $\alpha$ functions via inhibition of its expression and antagonizing its activities $(61,62,116,117)$. In the liver, cytokines such as interleukin-6 (IL-6) and TNF $\alpha$, are mainly produced from Kuppfer cells and hepatic stellate cells (HSC), and partly from inflamed hepatocytes $(52,118,119)$. Adiponectin ameliorates NASH and liver fibrosis through suppressing the activation of Kupffer cells and hepatic stellate cells (HSC) (Figure 2). In porcine blood-derived macrophages, adiponectin suppresses both TNF $\alpha$ and
IL6 production stimulated by LPS and induces IL10 expression. The attenuation of proinflammatory cytokine production by adiponectin is mediated in part by attenuating the translocation of NFKB to the nucleus (120). Adiponectin can also induce the expression of anti-inflammation cytokine interleukin-1-receptor antagonist (IL-1RA) $(121,122)$. The anti-inflammatory effects of adiponectin in macrophages may involve Toll-like receptor-4 (TLR-4) signaling pathway. However, the mechanisms by which adiponectin suppresses TLR- 4 mediated responses are not well understood (123).

The transformation of hepatic stellate cells (HSC) into myofibroblasts is the key step initiating the fibrotic process during liver injury $(124,125)$. The activated hepatic stellate cells increase the accumulation of extracellular matrix. Both adiponectin receptors, adipoRl and adipoR2, are expressed in HSC. Adiponectin treatment maintains HSC quiescence, inhibits platelet-derived growth factor (PDGF)-stimulated proliferation and migration of human HSCs, and reduces the secretion of monocyte chemoattractant protein-1 through AMPK-dependent mechanisms $(94,125,126)$. Additionally, adiponectin also regulates hepatic expression of TGF $\beta 1$, a pro-fibrotic factor involved in HSC activation $(58,127)$. Inhibition of adipoR2 expression by short hairpin RNAi-expressing adenovirus can induce TGF $\beta 1$ expression, and overexpression of adipoR 2 diminishes TGF $\beta 1$ mRNA level.

\section{Regulatory role of adiponectin on mitochondria activities}

Mitochondrial dysfunction represents a central mechanism linking obesity with associated metabolic complications (128). In patients with $\mathrm{NASH}$, the hepatic mitochondria exhibit ultrastructural lesions and decreased activity of the respiratory chain complexes $(129,130)$. In this condition, the decreased activity of the respiratory chain results in accumulation of reactive oxygen species (ROS) that oxidize fat deposits to form lipid peroxidation products, which in turn, cause steatohepatitis, necrosis, inflammation and fibrosis. The increased mitochondrial ROS formation in steatohepatitis could directly damage mitochondria DNA (mtDNA) and respiratory chain polypeptides, induce $\mathrm{NF \kappa B}$ activation and the hepatic synthesis of TNF $\alpha$ (131). Oxidative phosphorylation reactions mediated by mitochondria respiratory chain (MRC) complexes are directly involved in regulating intracellular ROS activities and 


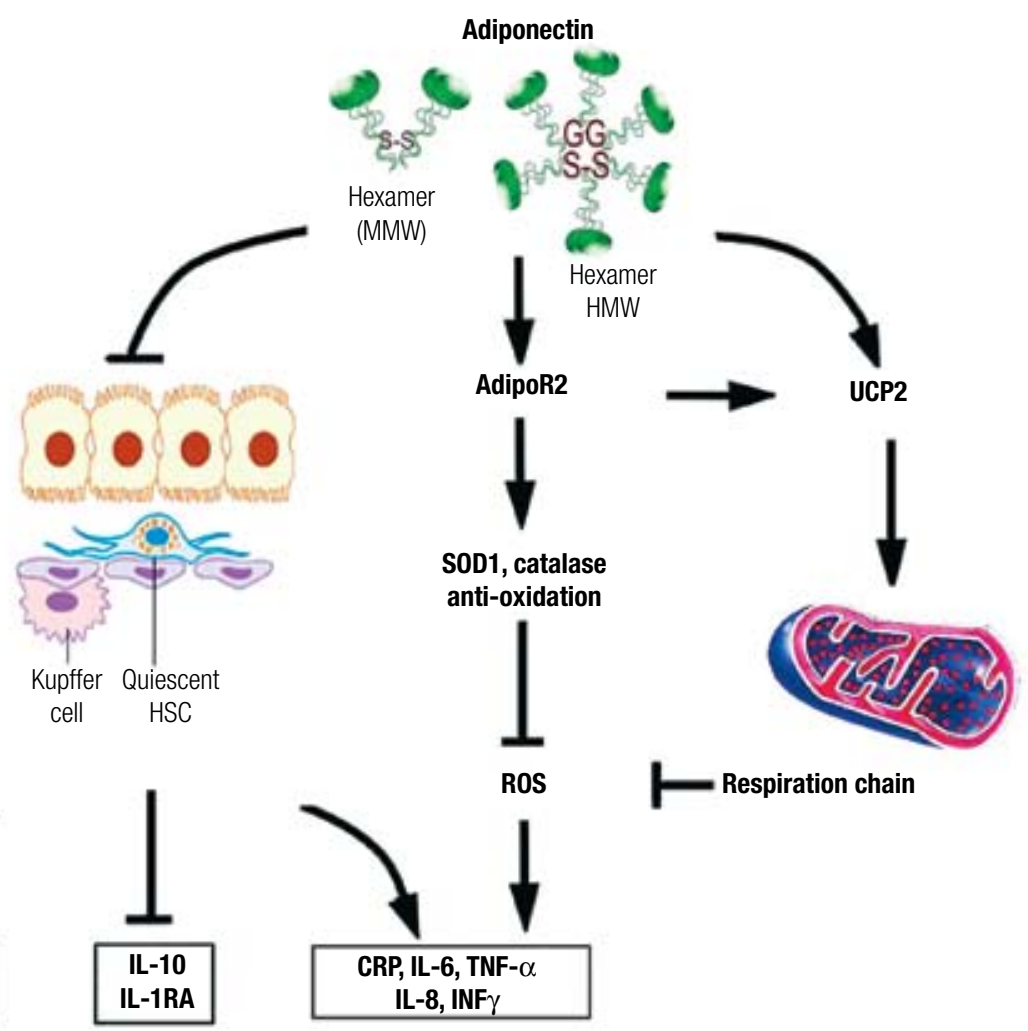

Fibrogeneis anti-inflammation proinflammation

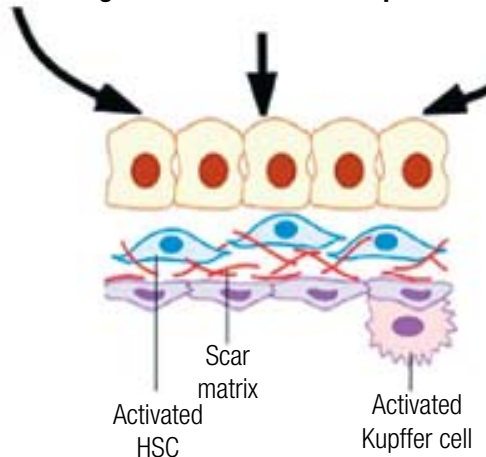

Figure 2. A summary of multiple pathways underlying the protective effects of adiponectin against liver injury.

preventing accumulation of lipids and lipid peroxidation products in the liver.

We have found that mice without adiponectin show an increased lipid accumulation even under normal chow feeding. This pre-existing hepatic steatotic condition might be the direct consequence of dysregulated mitochondria functions (117). Adiponectin treatment restores the MRC activities, decreases the levels of mitochondrial lipid peroxidation products through regulating hepatic mitochondrial functions, which might represent a common mechanism underlying the multiple beneficial activities of this hormone in various obesity-related pathologies. Moreover, we have provided evidence supporting an essential role of uncoupling protein 2 (UCP2), a mitochondria inner membrane transporter, in mediating the beneficial effects of adiponectin on MRC activities. The protein and mRNA levels of UCP2 are decreased in the liver tissues of adiponectin knockout mice and can be significantly up-regulated by adiponectin treatment. Over-expression of adipoR2 upregulates mRNA levels of UCP2, catalase, and superoxide dismutase 1 in the liver (97). Furthermore, the effects of adiponectin on the MRC activities are dramatically attenuated in Ucp2-deficient mice, suggesting that the increased UCP2 expression might be obligatory for adiponectin to elicit its activities on mitochondria 
functions (Figure 2). It is known that UCP2 possesses anti-oxidant activities through inhibition of ROS production from mitochondria (132). It can also inhibit the production of pro-inflammatory cytokines in both macrophage and Kupffer cells (133). A growing body of evidence suggests that UCP2 may play a beneficial role in various stages of fatty liver diseases $(133,134)$. These results suggest the existence of a reciprocal relationship between uncoupling proteins and adiponectin. However, the detailed signaling mechanisms underlying adiponectin-induced UCP2 expression are not clear and warrant further investigations.

\section{ELEVATION OF ADIPONECTIN PRODUCTION AS A THERAPEUTIC STRATEGY FOR THE TREATMENT OF NAFLD}

To date, there have been very few effective drug treatments for NAFLD and NASH. Early diagnosis and management of the underlying condition remains the mainstay of treatment. The present "gold standard" for treatment of NAFLD is weight reduction or a reduction of central obesity (4). These "life-style adjustment" or anti-obesity measures (including bariatric surgery) impressively reduce liver cell injury, inflammation and hepatic fibrosis, as well as steatosis $(135,136)$. The potential for correcting steatosis by dietary or pharmacological approaches should provide a sound therapeutic approach for the treatment of steatosis and steatohepatitis. Strategies to block oxidative stress are of great interest, with some evidence that ALT normalization or histological improvement occurs with vitamin $\mathrm{E}$ (alone or with vitamin $\mathrm{C}$ or pioglitazone) and betaine (137). However, more definitive studies are needed before these or other antioxidants and antifibrotic agents (including silymarin) can be routinely recommended.

Adiponectin and its agonists might represent emerging therapeutic agents for the treatment and/or prevention of liver dysfunctions. Adiponectin replacement therapy is not yet available as a treatment option. Pharmacological intervention aimed at elevating adiponectin production might hold promise for the treatment and/or prevention of NAFLD. We have recently reported the identification of two structurally related natural compounds (astragaloside II and isoastragaloside I) from the medicinal herb Radix Astragali that possess such an activity (138). Astragaloside II and isoastragaloside I selectively increase adiponectin secretion in primary adipocytes without any obvious effects on a panel of other adipokines. Furthermore, an additive effect on induction of adiponectin production has been observed between these two compounds and rosiglitazone. Chronic administration of astragaloside II and isoastragaloside I in both dietary and genetic obese mice significantly elevated serum levels of total adiponectin and selectively increased the composition of its high molecular weight oligomeric complex. These changes are associated with an alleviation of hyperglycemia, glucose intolerance and insulin resistance. These results suggest that pharmacological elevation of circulating adiponectin alone is sufficient to ameliorate insulin resistance and diabetes. The two natural compounds might also provide the lead as a novel class of therapeutics for obesity-related diseases, such as NAFLD.

\section{CONCLUSION REMARKS}

Adiponectin is an abundant adipocyte-derived hormone with well established anti-inflammatory and insulin sensitizing properties. The significance of adiponectin in protecting obesity-related NAFLD has been increasingly recognized. Despite the knowldege advances made in recent years, the detailed molecular and cellular mechanisms underlying its hepato-protective functions remain largely uncharacterized. Nevertheless, adiponectin-based therapeutics for NAFLD represent a promising area for further investigation.

Acknowledgement: Research in the author's laboratory is supported by grants from Research Grants Council of Hong Kong (Project number 777908, 778007 and 7645/06M).

Disclosure: No potential conflict of interest relevant to this article was reported.

\section{REFERENCES}

1. Angulo P. Nonalcoholic fatty liver disease. N Engl J Med. 2002; 346(16):1221-31.

2. Farrell GC. Non-alcoholic steatohepatitis: what is it, and why is it important in the Asia-Pacific region? J Gastroenterol Hepatol. 2003;18(2):124-38.

3. Matteoni CA, Younossi ZM, Gramlich T, Boparai N, Liu YC, McCullough AJ. Nonalcoholic fatty liver disease: a spectrum of clinical and pathological severity. Gastroenterology. 1999;116(6):1413-9.

4. Farrell GC, Larter CZ. Nonalcoholic fatty liver disease: from steatosis to cirrhosis. Hepatology. 2006;43(2 Suppl 1): S99-S112.

5. Adams LA, Angulo P. Recent concepts in non-alcoholic fatty liver disease. Diabet Med. 2005;22(9):1129-33.

6. Ong JP, Pitts A, Younossi ZM. Increased overall mortality and liver-related mortality in non-alcoholic fatty liver disease. $\mathrm{J} \mathrm{He}$ patol. 2008;49(4):608-12.

7. Targher G, Marra F, Marchesini G. Increased risk of cardiovascular disease in non-alcoholic fatty liver disease: causal effect or epiphenomenon? Diabetologia. 2008;51(11):1947-53. 
8. Watanabe S, Yaginuma R, Ikejima K, Miyazaki A. Liver diseases and metabolic syndrome. J Gastroenterol. 2008;43(7):509-18.

9. Machado $M$, Cortez-Pinto $H$. Non-alcoholic steatohepatitis and metabolic syndrome. Curr Opin Clin Nutr Metab Care. 2006;9(5):637-42.

10. Shibata M, Kihara Y,Taguchi M, Tashiro M, Otsuki M. Nonalcoholic fatty liver disease is a risk factor for type 2 diabetes in middleaged Japanese men. Diabetes Care. 2007;30(11):2940-4.

11. Machado $\mathrm{M}$, Cortez-Pinto $\mathrm{H}$. Non-alcoholic fatty liver disease and insulin resistance. Eur J Gastroenterol Hepatol; 2005;17(8):823-6.

12. Mehta K, Van Thiel DH, Shah N, Mobarhan S. Nonalcoholic fatty liver disease: pathogenesis and the role of antioxidants. Nutr Rev. 2002;60(9):289-93.

13. Gastaldelli A, Cusi K, Pettiti M, Hardies J, Miyazaki Y, Berria R, et al. Relationship between hepatic/visceral fat and hepatic insulin resistance in nondiabetic and type 2 diabetic subjects. Gastroenterology. 2007;133(2):496-506.

14. Vuguin P, Raab E, Liu B, Barzilai N, Simmons R. Hepatic insulin resistance precedes the development of diabetes in a model of intrauterine growth retardation. Diabetes. 2004;53(10):2617-22.

15. Blaak EE. Fatty acid metabolism in obesity and type 2 diabetes mellitus. Proc Nutr Soc. 2003;62(3);753-60.

16. DeFronzo RA, Gunnarsson R, Björkman O, Olsson M, Wahren J. Effects of insulin on peripheral and splanchnic glucose metabolism in noninsulin-dependent (type II) diabetes mellitus. J Clin Invest. 1985;76(1):149-55.

17. Banerji MA, Buckley MC, Chaiken RL, Gordon D, Lebovitz HE, Kral JG. Liver fat, serum triglycerides and visceral adipose tissue in insulin-sensitive and insulin-resistant black men with NIDDM. Int J Obes Relat Metab Disord. 1995;19(12):846-50.

18. Holland WL, Brozinick JT, Wang LP, Hawkins ED, Sargent KM, Liu $Y$, et al. Inhibition of ceramide synthesis ameliorates glucocorticoid-, saturated-fat-, and obesity-induced insulin resistance. Cell Metab. 2007;5(3):167-79.

19. Kelley DE, McKolanis TM, Hegazi RA, Kuller LH, Kalhan SC. Fatty liver in type 2 diabetes mellitus: relation to regional adiposity, fatty acids, and insulin resistance. Am J Physiol Endocrinol Metab. 2003;285(4):E906-16.

20. Assimacopoulos-Jeannet F, Brichard S, Rencurel F, Cusin I, Jeanrenaud $B$. In vivo effects of hyperinsulinemia on lipogenic enzymes and glucose transporter expression in rat liver and adipose tissues. Metabolism. 1995;44(2):228-33.

21. Minehira K, Young SG, Villanueva CJ, Yetukuri L, Oresic M, Hellerstein MK, et al. Blocking VLDL secretion causes hepatic steatosis but does not affect peripheral lipid stores or insulin sensitivity in mice. J Lipid Res. 2008;49(9):2038-44.

22. Grefhorst A, Hoekstra J, Derks TG, Ouwens DM, Baller JF, Havinga $R$, et al. Acute hepatic steatosis in mice by blocking betaoxidation does not reduce insulin sensitivity of very-low-density lipoprotein production. Am J Physiol Gastrointest Liver Physiol. 2005;289(3):G592-8.

23. Dentin R, Benhamed F, Hainault I, Fauveau V, Foufelle F, Dyck $\mathrm{JR}$, et al. Liver-specific inhibition of ChREBP improves hepatic steatosis and insulin resistance in ob/ob mice. Diabetes. 2006:55(8):2159-70.

24. Day CP, James OF. Steatohepatitis: a tale of two "hits"? Gastroenterology. 1998;114(4):842-5.

25. Brunt EM. Nonalcoholic steatohepatitis. Semin Liver Dis. 2004;24(1):3-20.

26. Charlton M. Noninvasive indices of fibrosis in NAFLD: starting to think about a three-hit (at least) phenomenon. Am J Gastroenterol. 2007;102(2):409-11.

27. de Luca C, Olefsky JM. Inflammation and insulin resistance. FEBS Lett. 2008;582(1):97-105.
28. Liou I, Kowdley KV. Natural history of nonalcoholic steatohepatitis. J Clin Gastroenterol. 2006;40 Suppl 1:S11-6.

29. Feldstein $A E$, Werneburg NW, Canbay A, Guicciardi ME, Bronk $S F$, Rydzewski $R$, et al. Free fatty acids promote hepatic lipotoxicity by stimulating TNF-alpha expression via a lysosomal pathway. Hepatology. 2004;40(1):185-94.

30. Jeong SK, Kim YK, Park JW, Shin YJ, Kim DS. Impact of visceral fat on the metabolic syndrome and nonalcoholic fatty liver disease. J Korean Med Sci. 2008;23(5):789-95.

31. van der Poorten D, Milner KL, Hui J, Hodge A, Trenell MI, Kench JG, et al. Visceral fat: a key mediator of steatohepatitis in metabolic liver disease. Hepatology. 2008;48(2):449-57.

32. Jakobsen MU, Berentzen T, Sørensen TI, Overvad K. Abdominal obesity and fatty liver. Epidemiol Rev. 2007;29:77-87.

33. Song $H R$, Yun KE, Park HS. Relation between alanine aminotransferase concentrations and visceral fat accumulation among nondiabetic overweight Korean women. Am J Clin Nutr. 2008;88(1):16-21.

34. Koda M, Kawakami M, Murawaki Y, Senda M. The impact of visceral fat in nonalcoholic fatty liver disease: cross-sectional and longitudinal studies. J Gastroenterol. 2007;42(11):897-903.

35. Gabriely I, Barzilai N. Surgical removal of visceral adipose tissue: effects on insulin action. Curr Diab Rep. 2003;3(3):201-6.

36. Antuna-Puente B, Feve B, Fellahi S, Bastard JP. Adipokines: the missing link between insulin resistance and obesity. Diabetes Metab. 2008;34(1):2-11

37. Kamada Y, Takehara T, Hayashi N. Adipocytokines and liver disease. J Gastroenterol. 2008;43(11):811-22.

38. Tilg H, Hotamisligil GS. Nonalcoholic fatty liver disease: Cytokine-adipokine interplay and regulation of insulin resistance. Gastroenterology. 2006;131(3):934-45.

39. Javor ED, Ghany MG, Cochran EK, Oral EA, DePaoli AM, Premkumar A, et al. Leptin reverses nonalcoholic steatohepatitis in patients with severe lipodystrophy. Hepatology. 2005;41(4):753-60.

40. Javor ED, Cochran EK, Musso C, Young JR, Depaoli AM, Gorden P. Long-term efficacy of leptin replacement in patients with generalized lipodystrophy. Diabetes. 2005;54(7):1994-2002.

41. Huang XD, Fan Y, Zhang $H$, Wang P, Yuan JP, Li MJ, Zhan XY. Serum leptin and soluble leptin receptor in non-alcoholic fatty liver disease. World J Gastroenterol., 2008;14(18):2888-93.

42. Kim IK, Kim J, Kang JH, Song J. Serum Leptin as a Predictor of Fatty Liver in 7-Year-Old Korean Children. Ann Nutr Metab. 2008;53(2):109-16.

43. Marra F. Leptin and liver tissue repair: do rodent models provide the answers? J Hepatol. 2007:46(1):12-8.

44. Crespo J, Cayón A, Fernández-Gil P, Hernández-Guerra M, Mayorga $M$, Domínguez-Díez $A$, et al. Gene expression of tumor necrosis factor alpha and TNF-receptors, p55 and p75, in nonalcoholic steatohepatitis patients. Hepatology. 2001;34(6):1158-63.

45. Ribeiro PS, Cortez-Pinto $H$, Solá $S$, Castro RE, Ramalho RM, Baptista A, et al. Hepatocyte apoptosis, expression of death receptors, and activation of NF-kappaB in the liver of nonalcoholic and alcoholic steatohepatitis patients. Am J Gastroenterol. 2004;99(9):1708-17.

46. Younossi ZM, Jarrar M, Nugent C, Randhawa M, Afendy M, Stepanova $\mathrm{M}$, et al. A novel diagnostic biomarker panel for obesity-related nonalcoholic steatohepatitis (NASH). Obes Surg. 2008;18(11):1430-7.

47. Li Z, Yang S, Lin $\mathrm{H}$, Huang J, Watkins PA, Moser AB, et al. Probiotics and antibodies to TNF inhibit inflammatory activity and improve nonalcoholic fatty liver disease. Hepatology. 2003;37(2):343-50.

48. Deng QG, She H, Cheng JH, French SW, Koop DR, Xiong S, Tsukamoto $\mathrm{H}$. Steatohepatitis induced by intragastric overfeeding in mice. Hepatology. 2005;42(4):905-14. 
49. Schnyder-Candrian S, Czarniecki J, Lerondel S, Corpataux J, Ryffel B, Schnyder B. Hepatic steatosis in the absence of tumor necrosis factor in mice. Cytokine. 2005;32(6):287-95.

50. Trujillo ME, Scherer PE. Adiponectin--journey from an adipocyte secretory protein to biomarker of the metabolic syndrome. J Intern Med. 2005;257(2):167-75.

51. Lopez-Bermejo A, Botas-Cervero P, Ortega-Delgado F, Delgado E, García-Gil MM, Funahashi T, et al. Adiponectin, hepatocellular dysfunction and insulin sensitivity. Clin Endocrinol (Oxf). 2004;60(2):256-63.

52. Hui JM, Hodge A, Farrell GC, Kench JG, Kriketos A, George J. Beyond insulin resistance in NASH: TNF-alpha or adiponectin? Hepatology. 2004;40(1):46-54.

53. Shimada M, Kawahara H, Ozaki K, Fukura M, Yano H, Tsuchishima $\mathrm{M}$, et al. Usefulness of a combined evaluation of the serum adiponectin level, HOMA-IR, and serum type IV collagen 7S level to predict the early stage of nonalcoholic steatohepatitis. Am J Gastroenterol. 2007;102(9):1931-8.

54. Musso G, Gambino R, Biroli G, Carello M, Fagà E, Pacini G, et al. Hypoadiponectinemia predicts the severity of hepatic fibrosis and pancreatic Beta-cell dysfunction in nondiabetic nonobese patients with nonalcoholic steatohepatitis. Am J Gastroenterol. 2005;100(11):2438-46.

55. Aygun C, Senturk O, Hulagu S, Uraz S, Celebi A, KondukT, et al. Serum levels of hepatoprotective peptide adiponectin in non-alcoholic fatty liver disease. Eur J Gastroenterol Hepatol. 2006;18(2):175-80.

56. Bajaj M, Suraamornkul S, Piper P, Hardies LJ, Glass L, Cersosimo $E$, et al. Decreased plasma adiponectin concentrations are closely related to hepatic fat content and hepatic insulin resistance in pioglitazone-treated type 2 diabetic patients. J Clin Endocrinol Metab. 2004;89(1):200-6.

57. Ikejima K, Okumura K, Kon K, Takei Y, Sato N. Role of adipocytokines in hepatic fibrogenesis. J Gastroenterol Hepatol. 2007;22 Suppl 1:S87-92.

58. Kamada Y, Tamura S, Kiso S, Matsumoto H, Saji Y, Yoshida Y, et al. Enhanced carbon tetrachloride-induced liver fibrosis in mice lacking adiponectin. Gastroenterology. 2003;125(6):1796-807.

59. Masaki T, Chiba S, Tatsukawa H, Yasuda T, Noguchi H, Seike M, Yoshimatsu H. Adiponectin protects LPS-induced liver injury through modulation of TNF-alpha in KK-Ay obese mice. Hepatology. 2004:40(1):177-84.

60. Matsumoto H, Tamura S, Kamada Y, Kiso S, Fukushima J, Wada A, et al. Adiponectin deficiency exacerbates lipopolysaccharide/ D-galactosamine-induced liver injury in mice. World J Gastroenterol. 2006;12(21):3352-8.

61. Thakur V, Pritchard MT, McMullen MR, Nagy LE. Adiponectin normalizes LPS-stimulatedTNF-alpha production by rat Kupffer cells after chronic ethanol feeding. Am J Physiol Gastrointest Liver Physiol. 2006;290(5):G998-1007.

62. Xu A , Wang Y, Keshaw H, Xu LY, Lam KS, Cooper GJ. The fat-derived hormone adiponectin alleviates alcoholic and nonalcoholic fatty liver diseases in mice. J Clin Invest. 2003;112(1):91-100.

63. Kamada $Y$, Matsumoto $H$, Tamura S, Fukushima J, Kiso S, Fukui $\mathrm{K}$, et al. Hypoadiponectinemia accelerates hepatic tumor formation in a nonalcoholic steatohepatitis mouse model. J Hepatol. 2007; 47:556-64.

64. Hu E, Liang P, Spiegelman BM. AdipoQ is a novel adipose-specific gene dysregulated in obesity. J Biol Chem. 1996;271:10697-703.

65. Maeda K, Okubo K, Shimomura I, Funahashi T, Matsuzawa Y, Matsubara K. cDNA cloning and expression of a novel adipose specific collagen-like factor, apM1 (AdiPose Most abundant Gene transcript 1). Biochem Biophys Res Commun. 1996;221:286-9.

66. Nakano $Y$, Tobe $T$, Choi-Miura NH, Mazda T, Tomita M. Isolation and characterization of GBP28, a novel gelatin-binding protein purified from human plasma. J Biochem. 1996;120:803-12.
67. Scherer PE, Williams S, Fogliano M, Baldini G, Lodish HF. A novel serum protein similar to $\mathrm{C} 1 \mathrm{q}$, produced exclusively in adipocytes. J Biol Chem. 1995;270:26746-9.

68. Kadowaki T, Yamauchi T, Kubota N, Hara K, Ueki K, Tobe K. Adiponectin and adiponectin receptors in insulin resistance, diabetes, and the metabolic syndrome. J Clin Invest. 2006;116:1784-92.

69. Lam KS, Xu A. Adiponectin: protection of the endothelium. Curr Diab Rep. 2005;5:254-9.

70. Yamauchi T, Hara K, Kubota N, Terauchi Y, Tobe K, Froguel P, et al. Dual roles of adiponectin/Acrp30 in vivo as an anti-diabetic and anti-atherogenic adipokine. Curr Drug Targets Immune Endocr Metabol Disord. 2003;3:243-54.

71. Zhu W, Cheng KK, Vanhoutte PM, Lam KS, Xu A. Vascular effects of adiponectin: molecular mechanisms and potential therapeutic intervention. Clin Sci (Lond). 2008;114:361-74.

72. Oh DK, Ciaraldi T, Henry RR. Adiponectin in health and disease. Diabetes Obes Metab. 2007;9:282-9.

73. Wang Y, Lam KS, Yau MH, Xu A. Post-translational modifications of adiponectin: mechanisms and functional implications. Biochem J. 2008;409:623-33.

74. Tsao TS, Murrey HE, Hug C, Lee DH, Lodish HF. Oligomerization state-dependent activation of NF-kappa B signaling pathway by adipocyte complement-related protein of $30 \mathrm{kDa}$ (Acrp30). J Biol Chem. 2002;277:29359-62.

75. Tsao TS, Tomas E, Murrey HE, Hug C, Lee DH, Ruderman NB, et al. Role of disulfide bonds in Acrp30/adiponectin structure and signaling specificity. Different oligomers activate different signal transduction pathways. J Biol Chem. 2003;278:50810-7.

76. Waki H, Yamauchi T, Kamon J, Ito Y, Uchida S, Kita S, et al. Impaired multimerization of human adiponectin mutants associated with diabetes. Molecular structure and multimer formation of adiponectin. J Biol Chem. 2003;278:40352-63.

77. Xu A, Chan KW, Hoo RL, Wang Y, Tan KC, Zhang J, et al. Testosterone selectively reduces the high molecular weight form of adiponectin by inhibiting its secretion from adipocytes. J Biol Chem. 2005;280:18073-80.

78. Richards AA, Stephens T, Charlton HK, Jones A, Macdonald GA, Prins JB, Whitehead JP. Adiponectin multimerization is dependent on conserved lysines in the collagenous domain: evidence for regulation of multimerization by alterations in posttranslational modifications. Mol Endocrinol. 2006;20:1673-87.

79. Pajvani UB, Du X, Combs TP, Berg AH, Rajala MW, Schulthess $T$, et al. Structure-function studies of the adipocyte-secreted hormone Acrp30/adiponectin. Implications fpr metabolic regulation and bioactivity. J Biol Chem. 2003;278:9073-85.

80. Wang $Y, X u A$, Knight $C, X u$ LY, Cooper GJ. Hydroxylation and glycosylation of the four conserved lysine residues in the collagenous domain of adiponectin. Potential role in the modulation of its insulin-sensitizing activity. J Biol Chem. 2002;277:19521-9.

81. Pajvani UB, Hawkins M, CombsTP, Rajala MW, DoebberT, Berger $\mathrm{JP}$, et al. Complex distribution, not absolute amount of adiponectin, correlates with thiazolidinedione-mediated improvement in insulin sensitivity. J Biol Chem. 2004;279:12152-62.

82. Suzuki S, Wilson-Kubalek EM, Wert D, Tsao TS, Lee DH. The oligomeric structure of high molecular weight adiponectin. FEBS Lett. 2007:581:809-14.

83. Radjainia M, Wang Y, Mitra AK. Structural polymorphism of oligomeric adiponectin visualized by electron microscopy. J Mol Biol. 2008;381:419-30.

84. Bobbert T, Rochlitz H, Wegewitz U, Akpulat $\mathrm{S}$, Mai K, Weickert $\mathrm{MO}$, et al. Changes of adiponectin oligomer composition by moderate weight reduction. Diabetes. 2005;54:2712-9.

85. Salani B, Briatore L, Andraghetti G, Adami GF, Maggi D, Cordera R. High-molecular weight adiponectin isoforms increase after bi- 
liopancreatic diversion in obese subjects. Obesity (Silver Spring). 2006;14:1511-4.

86. Swarbrick MM, Austrheim-Smith IT, Stanhope KL, Van Loan MD, Ali MR, Wolfe BM et al. Circulating concentrations of high-molecular-weight adiponectin are increased following Roux-en-Y gastric bypass surgery. Diabetologia. 2006;49:2552-8.

87. Liu Y, Retnakaran R, Hanley A, Tungtrongchitr R, Shaw C, Sweeney $\mathrm{G}$. Total and high molecular weight but not trimeric or hexameric forms of adiponectin correlate with markers of the metabolic syndrome and liver injury in Thai subjects. J Clin Endocrinol Metab. 2007;92:4313-8.

88. Berg AH, Combs TP, Du X, Brownlee M, Scherer PE. The adipocyte-secreted protein Acrp30 enhances hepatic insulin action. Nat Med. 2001;7:947-53.

89. Wang Y, Lam KS, Chan L, Chan KW, Lam JB, Lam MC, et al. Posttranslational modifications of the four conserved lysine residues within the collagenous domain of adiponectin are required for the formation of its high molecular weight oligomeric complex. $J$ Biol Chem. 2006;281:16391-400.

90. Kubota $N$, Terauchi $Y$, Kubota $T$, Kumagai $H$, Itoh $S$, Satoh $H$, et al. Pioglitazone ameliorates insulin resistance and diabetes by both adiponectin-dependent and -independent pathways. J Biol Chem. 2006;281:8748-55.

91. Nawrocki AR, Rajala MW, Tomas E, Pajvani UB, Saha AK, Trumbauer ME, et al. Mice lacking adiponectin show decreased hepatic insulin sensitivity and reduced responsiveness to peroxisome proliferator-activated receptor gamma agonists. J Biol Chem. 2006;281:2654-60.

92. Wang Y, Lu G, Wong WP, Vliegenthart JF, Gerwig GJ, Lam KS, et al. Proteomic and functional characterization of endogenous adiponectin purified from fetal bovine serum. Proteomics. 2004;4:3933-42.

93. Neumeier M, Sigruener A, Eggenhofer E, Weigert J, Weiss TS, Schaeffler $A$, et al. High molecular weight adiponectin reduces apolipoprotein $B$ and $E$ release in human hepatocytes. Biochem Biophys Res Commun. 2007;352:543-8.

94. Adachi M, Brenner DA. High molecular weight adiponectin inhibits proliferation of hepatic stellate cells via activation of adenosine monophosphate-activated protein kinase. Hepatology. 2008:47:677-85.

95. Kadowaki T, Yamauchi T. Adiponectin and adiponectin receptors. Endocr Rev. 2005;26:439-51.

96. Kadowaki T, Yamauchi T, Kubota N. The physiological and pathophysiological role of adiponectin and adiponectin receptors in the peripheral tissues and CNS. FEBS Lett. 2008;582:74-80.

97. Yamauchi T, Nio Y, Maki T, Kobayashi M, Takazawa T, Iwabu M, et al. Targeted disruption of AdipoR1 and AdipoR2 causes abrogation of adiponectin binding and metabolic actions. Nat Med. 2007;13:332-9.

98. Liu Y, Michael MD, Kash S, Bensch WR, Monia BP, Murray SF, et al. Deficiency of adiponectin receptor 2 reduces diet-induced insulin resistance but promotes type 2 diabetes. Endocrinology. 2007;148:683-92.

99. Kaser S, Moschen A, Cayon A, Kaser A, Crespo J, Pons-Romero $\mathrm{F}$, et al. Adiponectin and its receptors in non-alcoholic steatohepatitis. Gut. 2005;54:117-21.

100. Nannipieri M, Cecchetti F, Anselmino M, Mancini E, Marchetti G, Bonotti $A$, et al. Pattern of expression of adiponectin receptors in human liver and its relation to nonalcoholic steatohepatitis. Obes Surg. 2008;oct 16 [Epub ahead of print].

101. Uribe $M$, Zamora-Valdés $D$, Moreno-Portillo $M$, Bermejo-Martínez L, Pichardo-Bahena R, Baptista-González HA, et al. Hepatic expression of ghrelin and adiponectin and their receptors in patients with nonalcoholic fatty liver disease. Ann Hepatol. 2008;7:67-71.
102. Vuppalanchi R, Marri S, Kolwankar D, Considine RV, Chalasani N. Is adiponectin involved in the pathogenesis of nonalcoholic steatohepatitis? A preliminary human study. J Clin Gastroenterol. 2005;39:237-42.

103. Cheng KK, Lam KS, Wang Y, Huang Y, Carling D, Wu D, et al. Adiponectin-induced endothelial nitric oxide synthase activation and nitric oxide production are mediated by APPL1 in endothelial cells. Diabetes. 2007;56:1387-94.

104. Yamauchi T, Kamon J, Minokoshi $Y$, Ito $Y$, Waki H, Uchida S, et al. Adiponectin stimulates glucose utilization and fatty-acid oxidation by activating AMP-activated protein kinase. Nat Med. 2002;8:1288-95.

105. Shibata R, Ouchi N, Ito M, Kihara S, Shiojima I, Pimentel DR, et al. Adiponectin-mediated modulation of hypertrophic signals in the heart. Nat Med. 2004;10:1384-9.

106. Kubota N, Yano W, Kubota T, Yamauchi T, Itoh S, Kumagai $H$, et al. Adiponectin stimulates AMP-activated protein kinase in the hypothalamus and increases food intake. Cell Metab. 2007;6:55-68.

107. Mao X, Kikani CK, Riojas RA, Langlais P, Wang L, Ramos FJ, et al. APPL1 binds to adiponectin receptors and mediates adiponectin signalling and function. Nat Cell Biol. 2006;8:516-23.

108. Chandrasekar B, Boylston WH, Venkatachalam K, Webster NJ, Prabhu SD, Valente AJ. Adiponectin blocks interleukin-18-mediated endothelial cell death via APPL1-dependent AMP-activated protein kinase (AMPK) activation and IKK/NF-kappaB/PTEN suppression. J Biol Chem. 2008;283:24889-98.

109. Saito T, Jones CC, Huang S, Czech MP, Pilch PF. The interaction of Akt with APPL1 is required for insulin-stimulated Glut4 translocation. J Biol Chem. 2007;282:32280-7.

110. Woods A, Azzout-Marniche D, Foretz M, Stein SC, Lemarchand P, Ferré $P$, et al. Characterization of the role of AMP-activated protein kinase in the regulation of glucose-activated gene expression using constitutively active and dominant negative forms of the kinase. Mol Cell Biol. 2000;20:6704-11.

111. Tomita K, Tamiya G, Ando S, Kitamura N, Koizumi H, Kato S, et al. AICAR, an AMPK activator, has protective effects on alcohol-induced fatty liver in rats. Alcohol Clin Exp Res. 2005;29 Suppl12:240S-5S.

112. You M, Considine RV, Leone TC, Kelly DP, Crabb DW. Role of adiponectin in the protective action of dietary saturated fat against alcoholic fatty liver in mice. Hepatology. 2005;42:568-77.

113. Carter-Kent C, Zein NN, Feldstein AE. Cytokines in the pathogenesis of fatty liver and disease progression to steatohepatitis: implications for treatment. Am J Gastroenterol. 2008;103:1036-42.

114. Choi KM, Ryu OH, Lee KW, Kim HY, Seo JA, Kim SG, et al. Serum adiponectin, interleukin-10 levels and inflammatory markers in the metabolic syndrome. Diabetes Res Clin Pract. 2007;75:235-40.

115. Engeli S, Feldpausch M, Gorzelniak K, Hartwig F, Heintze U, Janke $\mathrm{J}$, et al. Association between adiponectin and mediators of inflammation in obese women. Diabetes. 2003;52:942-7.

116. Park PH, Thakur V, Pritchard MT, McMullen MR, Nagy LE. Regulation of Kupffer cell activity during chronic ethanol exposure: role of adiponectin. J Gastroenterol Hepatol. 2006;21 Suppl 3:S30-3.

117. Zhou M, Xu A, Tam PK, Lam KS, Chan L, Hoo RL, et al. Mitochondrial dysfunction contributes to the increased vulnerabilities of adiponectin knockout mice to liver injury. Hepatology. 2008;48:1087-96.

118. Choi S, Diehl AM. Role of inflammation in nonalcoholic steatohepatitis. Curr Opin Gastroenterol. 2005;21:702-7.

119. Jarrar MH, Baranova A, Collantes R, Ranard B, Stepanova M, Bennett $\mathrm{C}$, et al. Adipokines and cytokines in non-alcoholic fatty liver disease. Aliment PharmacolTher. 2008;27:412-21.

120. Wulster-Radcliffe MC, Ajuwon KM, Wang J, Christian JA, Spurlock ME. Adiponectin differentially regulates cytokines in porcine macrophages. Biochem Biophys Res Commun. 2004;316:924-9. 
121. Kumada M, Kihara S, Ouchi N, Kobayashi H, Okamoto Y, Ohashi $\mathrm{K}$, et al. Adiponectin specifically increased tissue inhibitor of metalloproteinase- 1 through interleukin-10 expression in human macrophages. Circulation. 2004;109:2046-9.

122. Wolf $A M$, Wolf $D$, Rumpold $H$, Enrich B, Tilg H. Adiponectin induces the anti-inflammatory cytokines IL-10 and IL-1RA in human leukocytes. Biochem Biophys Res Commun. 2004;323:630-5.

123. Yamaguchi N, Argueta JG, Masuhiro Y, Kagishita M, Nonaka K, Saito T, et al. Adiponectin inhibits Toll-like receptor family-induced signaling. FEBS Lett. 2005;579:6821-6.

124. Bertolani C, Marra F. The role of adipokines in liver fibrosis. Pathophysiology. 2008;15:91-101.

125. Ding X, Saxena NK, Lin S, Xu A, Srinivasan S, Anania FA. The roles of leptin and adiponectin: a novel paradigm in adipocytokine regulation of liver fibrosis and stellate cell biology. Am J Pathol. 2005;166:1655-69.

126. Caligiuri A, Bertolani C, Guerra CT, Aleffi S, Galastri S, Trappoliere $\mathrm{M}$, et al. Adenosine monophosphate-activated protein kinase modulates the activated phenotype of hepatic stellate cells. Hepatology. 2008;47:668-76.

127. Tomita K, Oike Y, Teratani T, Taguchi T, Noguchi M, Suzuki T, et al. Hepatic AdipoR2 signaling plays a protective role against progression of nonalcoholic steatohepatitis in mice. Hepatology. 2008;48:458-73.

128. Parish R, Petersen KF. Mitochondrial dysfunction and type 2 diabetes. Curr Diab Rep. 2005;5:177-83.

129. Perez-Carreras M, Del Hoyo P, Martín MA, Rubio JC, Martín A, Castellano G, et al. Defective hepatic mitochondrial respiratory chain in patients with nonalcoholic steatohepatitis. Hepatology. 2003;38:999-1007.
130. Sanyal AJ, Campbell-Sargent C, Mirshahi F, Rizzo WB, Contos MJ, Sterling RK, et al. Nonalcoholic steatohepatitis: association of insulin resistance and mitochondrial abnormalities. Gastroenterology. 2001;120:1183-92.

131. Fromenty B, Robin MA, Igoudjil A, Mansouri A, Pessayre D. The ins and outs of mitochondrial dysfunction in NASH. Diabetes Metab. 2004;30:121-38.

132. Negre-Salvayre A, Hirtz C, Carrera G, Cazenave R, Troly M, Salvayre $R$, et al. A role for uncoupling protein- 2 as a regulator of mitochondrial hydrogen peroxide generation. FASEB J. 1997;11:809-15.

133. Bai $Y$, Onuma H, Bai X, Medvedev AV, Misukonis M, Weinberg $\mathrm{JB}$, et al. Persistent nuclear factor-kappa B activation in Ucp2-/mice leads to enhanced nitric oxide and inflammatory cytokine production. J Biol Chem. 2005;280:19062-9.

134. Baffy G. Uncoupling protein-2 and non-alcoholic fatty liver disease. Front Biosci. 2005;10:2082-96.

135. Petersen KF, Dufour S, Befroy D, Lehrke M, Hendler RE, Shulman $\mathrm{Gl}$. Reversal of nonalcoholic hepatic steatosis, hepatic insulin resistance, and hyperglycemia by moderate weight reduction in patients with type 2 diabetes. Diabetes. 2005;54:603-8.

136. Dixon JB, Bhathal PS, Hughes NR, O'Brien PE. Nonalcoholic fatty liver disease: Improvement in liver histological analysis with weight loss. Hepatology. 2004;39:1647-54.

137. Angulo P. Current best treatment for non-alcoholic fatty liver disease. Expert Opin Pharmacother. 2003;4:611-23.

138. Xu A, Wang H, Hoo RL, Sweeney G, Vanhoutte PM, Wang Y, et al. Selective elevation of adiponectin production by the natural compounds derived from a medicinal herb alleviates insulin resistance and glucose intolerance in obese mice. Endocrinology. 2009;150:625-33. 